\title{
LITHUANIAN ACHIEVEMENTS IN TERMS OF CO2 EMISSIONS BASED ON PRODUCTION SIDE IN THE CONTEXT OF THE EU-27
}

\author{
Genovaite LIOBIKIENĖa, Justina MANDRAVICKAITE் $\dot{b}^{\mathrm{b}}$, Danguolè \\ KREPŠTULIENÉc, Jurga BERNATONIENE ${ }^{a}$, Arūnas SAVICKAS ${ }^{\mathrm{a}}$ \\ ${ }^{a}$ Departament of Drug Technology and Social Pharmacy, Lithuanian University of Health Sciences, \\ Eiveniu g. 4, LT-50009 Kaunas, Lithuania \\ ${ }^{b}$ Baltic Institute of Advanced Technology, Sauletekio al. 15, 10224 Vilnius, Lithuania \\ ${ }^{c}$ Department of Statistics of Agriculture and Environment at the Statistics Lithuania, \\ Gedimino pr. 29, Vilnius, Lithuania
}

Received 17 July 2014; accepted 29 March 2015

\begin{abstract}
The production perspective is actual seeking regarding the $\mathrm{CO} 2$ emissions management policy; however, there is a lack of studies taking the latter approach. Thus referring to air emissions accounts, the aim of this analysis is to evaluate changes in $\mathrm{CO} 2$ equivalent emissions from the production-based perspective in Lithuania and the EU-27 and their determinants during 20002012. Using the coefficient of elasticity, it was observed that in Lithuanian the economy grew three times faster than emissions of greenhouse gases (GHG). Meanwhile in the EU-27, GHG decreased with economic growth. In the EU-27 absolute decoupling was observed for agriculture, forestry and fishing, public administration, defence economic activities, real estate activities, and education. Meanwhile, in Lithuania for these activities a relative or negative decoupling occurred. With regard to technological contributions to changes in $\mathrm{CO} 2$ equivalent emissions, the most problematic economic activities in Lithuania are financial and insurance activities, education, post and telecommunications, other service activities. In the EU-27 members the most problematic sectors are mining and quarrying, construction, transport and storage sector. Thus, the successful implementation of GHG emissions management policy is very important in Lithuania and in all the EU countries.
\end{abstract}

Keywords: environmental policy, production, decoupling, technology, GHG emissions.

JEL Classification: Q53, C40, R11, O33.

\section{Introduction}

Climate change is becoming one of the most severe challenges human society faces this century (Camarero et al. 2013; Li, Lin 2013; Herrerias 2013). Therefore, prevention of climate change by reducing and stabilizing carbon dioxide emissions are the most important

Corresponding author Genovaitè Liobikienè

E-mail: g.liobikiene@gmf.vdu.lt 
concerns for policymakers and international institutions. Thus, issues concern measures to be adopted to achieve lower emissions of carbon dioxide and the magnitude of emission reduction to be put on agenda in both international negotiations and policies of countries around the world (Liao, Cao 2013).

In order to stabilize greenhouse gas (GHG) emissions and mitigate anthropogenic impacts on climate change, the Kyoto protocol set particular commitments to reduce GHG emissions. Based on the protocol, by 2008-2012 the EU has to reduce GHG below 1990 level by $8 \%$. Most of the New Member States (including Lithuania) have the same target. Additionally, the EU has also played a very active role in the quest for post-Kyoto international agreements involving countries in the fight against climate change (Erisman et al. 2008; Padilla, Duro 2013). The EU has assumed a great commitment to fight climate change at a worldwide level by approving the Europe 2020 strategy. This strategy defines commitment by 2020 to reduce the greenhouse gas emissions of 1990 by $20 \%$ (to be extended to $30 \%$ if other developed countries assume a similar objective), to decrease primary energy use by $20 \%$ by improving energy efficiency and to increase share of renewable resources in EU energy consumption to 20\% (EC 2012). Moreover, in order to achieve long-term goals and gradually transform Europe into low carbon economy, the EU has pledged by 2050 to reduce $\mathrm{CO} 2$ equivalent pollution by $80 \%$ in comparison to 1990 (EC 2011b).

Nevertheless, J. Brizga et al. (2014) stated that none of the Baltic States, including Lithuania, has a clear national policy framework to support GHG emissions reduction, even though the reduction of greenhouse gas emissions is one of the main priorities in the Lithuanian sustainable development strategy (The Lithuanian strategy... 2009). However, the Parliament of the Republic of Lithuania approved the National strategy for climate change management policy in 2012. The purpose of the Strategy is to develop and implement Lithuanian climate change management policy and set short-term (by 2020), indicated medium-term (by 2030 and 2040) and long-term (by 2050) climate change mitigation and adaptation goals and objectives.

For implementation of climate change management policy, it is important to highlight that growth of $\mathrm{CO} 2$ emissions is largely influenced by anthropogenic factors, especially by production activities that require fossil fuels (Parikh et al. 2009; EEA 2010). Therefore, the environmental performance of industries is an issue of increasing concern for both policymakers and researchers in the field of environmental economics (Camarero et al. 2008; Zavadskas, Turskis 2011). The production perspective takes into account the responsibility of countries-producers considering direct emissions in a particular country due to domestic production processes that generate pressures and impacts within that country (Peters 2008; Wood 2009; Marin et al. 2012). Thus in the Lithuanian national strategy for climate change management policy (2012) proposals related to shared efforts to meet greenhouse gas reduction commitment in sectors covered and not covered in the EU emissions trading system (such as transport, agriculture and industry) are also included. Therefore, to achieve the commitment of the $\mathrm{CO} 2$ equivalent management policy it is important to explore changes in GHG emissions from the production-based perspective (Li, Lin 2013).

$\mathrm{CO} 2$ emissions are released mostly due to the growth of production level which determines the increase in consumption and economic growth (Kerkhof et al. 2009; Jobert et al. 
2010; Girod, Haan 2010; Finel, Tapio 2012). Hence it is essential that negative environmental impact coming with economic growth would increase more slowly (relative decoupling) or slow down (absolute decoupling). The achievement of the decoupling process is revealed by the elasticity coefficient which is considered as a ratio of the percentage change in GHG emissions to the percentage change in GDP (Vehmas et al. 2003, 2007; Kerkhof et al. 2009; Jobert et al. 2010; Girod, Haan 2010; Finel, Tapio 2012).

Thus, when pursuing economic growth, greenhouse gas emissions in total should increase at slower rate or decrease. The most important tools for emission reduction are production structure changes: faster economic growth in less polluting (services) sectors than in more polluting sectors (Parikh et al. 2009; Wood 2009; Butnar, Liop 2011; Liu, Wang 2013; Brizga et al. 2014) as well as advanced technologies and innovations (Kim, K., Kim, Y. 2012; Hammond, Norman 2012; Zhang et al. 2012; Alves, Moutinho 2013; Wang et al. 2013; Dai et al. 2013; Baležentis et al. 2013; Voigt et al. 2014).

Technological contributions are determined by foreign direct investment, imports of machinery and equipment as well as human capital (Arazmuradov et al. 2013). However, innovations themselves may generate environmental pressure as they may increase resource consumption and environmental pollution. This is shown by the rebound effect, in which responses tend to offset the beneficial effects of the new technology (Freire-Gonzalez 2011; Turner, Hanley 2011). Notwithstanding, more technical efficiency in the production process, which refers to ability to maximize outputs from a given inputs or to minimize input utilization of given outputs (Arazmuradov et al. 2013), is a goal in the pursuit of the long-term aims (Voigt et al. 2014) of GHG emission reduction policy. Moreover, it is very important to increase energy efficiency and to promote generation of electricity without using fossil fuels.

Considering that the EU is the third largest CO2 emitter in the world, $\mathrm{CO} 2$ emission research has gained a lot of attention. P. Fernández González et al. (2014) applied decomposition analysis and evaluated that in the period 2001-2008 in the EU-27 countries a small drop in $\mathrm{CO} 2$ emissions was observed. However, Lithuania was one of the EU countries where $\mathrm{CO} 2$ emission increased. Notwithstanding, there are few studies in GHG emissions that take production-based perspective. Thus the aims of this analysis are the following: to evaluate changes in air pollution from the production-based perspective in Lithuania and in the EU-27 member states during 2000-2012, to assess economic impact of changes in $\mathrm{CO} 2$ equivalent emissions, to evaluate technological contributions to changes in GHG emissions in separate economic activities and to review existing climate change mitigation policy in Lithuania and the EU.

Thus, the rest of the paper proceeds as follows. Section 1 presents methods used in the assessment of air emissions accounts, economic impact on greenhouse gas emissions and evaluation of technological contributions to changes in GHG emissions in Lithuania as well as the EU-27 member states. Section 2 discusses results of changes in GHG emissions, effects on the economy regarding these changes and technological contributions, and a review of GHG emission management policy. Finally, the last Section closes the paper with the main conclusions. 


\section{Methods and data}

In order to evaluate changes in GHG emissions caused by production-based activities, air emissions accounts data of 14 economic activities groups (Appendix A) there were used.

Environmental economic accounts provide an integrated framework for data, indicators and analysis. The first European regulation of environmental accounts was adopted in 2011 (Regulation (EU) No 691/2011).

\subsection{Method for compilation of air emission accounts}

For compilation of air emissions accounts, the "inventory-first-approach" was used. This approach contributes to the implementation of Community statistical programmes and the EU legislation related to development of statistical areas. The "inventory-first-approach" starts from inventories of existing national emission data and re-arranges these data to a format compatible with national accounts. GHG emission inventories (based upon a process-oriented classification) have been compiled following the 1996 IPCC Guidelines for National Greenhouse Gas Inventories. Hence when compiling air emissions accounts, the following two main adjustments for the "inventory-first-approach" to the emissions inventory data were applied:

- The emissions caused by resident economic units were estimated starting with the emissions caused by all emission sources (economic and non-economic) in certain geographic territory.

- The inventory data following a process-oriented classification were assigned to economic activities (e.g. NACE rev.1).

There is no standard connection between processes and air emission accounts' activities. In order to shift from the process-based SNAP classification to the activity-based NACE rev. 1 classification, an analysis of quantitative links between each SNAP process and NACE rev. 1 activities, i.e. identification of NACE rev.1 activities in which a SNAP process takes place, was performed.

Furthermore, the following criteria were used to analyze differences between environmental data and air emissions accounts:

- emissions from each SNAP process are always attributed to NACE rev.1 activities that directly produce them (general rule);

- emissions from secondary and ancillary activities were allocated on the basis of criteria used for construction of economic accounts (i.e. industries);

- emissions from each SNAP process were attributed to NACE rev.1 depending on how the emissions were actually produced.

According to de Leeuw (2002), GHG emissions (CO2 equivalent) were aggregated referring to carbon dioxide $(\mathrm{CO} 2)$, methane $(\mathrm{CH} 4)$ and nitrous oxide $(\mathrm{N} 2 \mathrm{O})$ emissions. 


\subsection{Economic determinants to changes of greenhouse gases emissions}

In order to evaluate influence of economic changes to GHG emissions, elasticity coefficient there was applied. In this instance, the elasticity coefficient is defined as ratio of percentage change in $\mathrm{CO} 2$ equivalent emissions of separate economic activity to percentage change in gross value added (VA). The elasticity coefficient was calculated using a regression model. The coefficient $b$ from this regression model could be directly read as the elasticity coefficient (Vehmas et al. 2003, 2007; Kerkhof et al. 2009; Jobert et al. 2010; Girod, Haan 2010; Finel, Tapio 2012). Thus, the equation is specified as follows:

$$
\ln (\mathrm{CO} 2 \mathrm{i})=\mathrm{a}+\mathrm{b}^{\star}(\ln \mathrm{VAi})
$$

in which $\mathrm{CO} 2 \mathrm{i}$ is the amount of air emissions from $\mathrm{i}$ economic activity in tonnes, VAi value added of $i$ economic activity in constant prices.

Firstly, elasticity coefficient shows how many changes in $\mathrm{CO} 2$ emissions occurred when economy grows by $1 \%$. Moreover, elasticity value reveals what process of decoupling occurred during the period of 2000-2012.

In the Figure 1 decoupling values are depicted. With economic growth, a negative coefficient of elasticity means that GHG emissions decrease and that the absolute decoupling process proceeds. When the coefficient is $0<\mathrm{b}<1$, it shows that air pollution increases at a slower rate than VA, and it reveals the occurrence of relative decoupling. When it is $b>$ 1 , it shows that negative decoupling happens, meaning that air pollution increases more than VA and from an environmental perspective it is viewed very negatively.

With economic shrinkage, an elasticity coefficient of $\mathrm{b}>1$ shows that emissions decrease more than VA and it reveals the occurrence of recessive decoupling. When $0<\mathrm{b}<$ 1 , it conveys that recessive decoupling process is negative, i.e. VA decreased more than $\mathrm{CO} 2$ emissions. Finally, negative elasticity coefficient reveals that strong negative decoupling occurs and it means that though economic reduction occurred, the pollution increased. From the environmental perspective this process would be unacceptable.

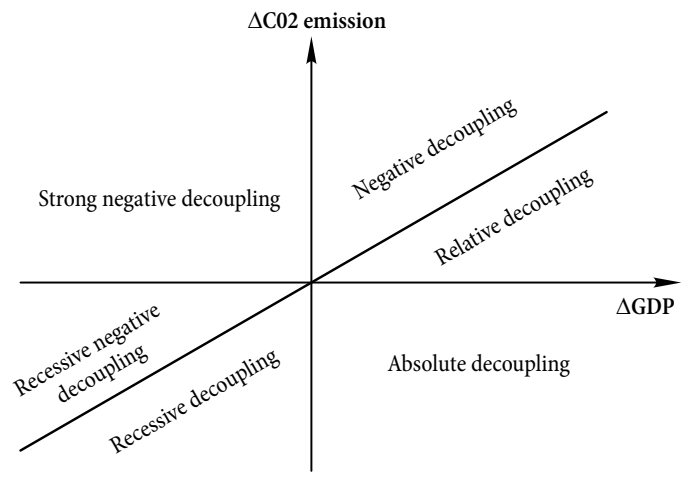

Fig. 1. The decoupling diagram 


\subsection{Technology contribution to changes in GHG emissions}

The last part of this study is devoted to analysis of technological contribution to changes in GHG emissions. Definition of technology in this article includes not only technological progress, but also other instruments, such as renewable energy consumption, expansion of eco-labeled agriculture and other tools related to GHG emission intensity reduction. Firstly, in order to evaluate technological contribution, the emission intensity coefficient is used and equation is specified as follows:

$$
\mathrm{In}=\frac{\mathrm{CO} 2 \mathrm{i}}{\mathrm{VAi}} .
$$

For further evaluation of technological contribution to changes in GHG emissions, two scenarios there were compared. In the first scenario the air emissions intensity coefficient is calculated for 2000. As this coefficient during the analyzed period is constant, it is assumed that $\mathrm{CO} 2$ equivalent emissions grew at the same rate as their economic activities. Therefore, the air emissions intensity coefficient in the year 2000 is multiplied by account of VA in the year 2012.This value revealed changes in GHG emissions in scenario where technological development did not occur and the level of emission intensity was uniform as in 2000 .

The second scenario is based on the real growth of air emissions from economic activities. It conveys real changes in emissions and the emission intensity coefficient. The difference between these two scenarios in 2012 reveals technological contribution to changes in GHG emissions of distinct economic activities.

\section{Results}

\subsection{Changes in $\mathrm{CO} 2$ equivalent emissions in Lithuania and the EU-27 member states}

According to data of the Eurostat database, we evaluated that GHG emissions from production based perspective amount to about $83 \%$ of total $\mathrm{CO} 2$ equivalent emissions in the EU-27 members. Meanwhile, in Lithuania this amount is about 95\%. These results show that examination of $\mathrm{CO} 2$ equivalent emissions is very important. Evaluation of alterations in these emissions and the determinants of changes in them contribute to propositions not only regarding production-based level but also air emissions of the countries in total.

Analysis of CO2 equivalent emissions of total economic activities (Fig. 2) shows that the amount of emissions per capita in Lithuania is smaller than in the EU-27. The reason could be that the level of production in Lithuania is lower than in the EU-27. Besides, there are differences in the scope of export, import and consumption. Thus according to data of the Eurostat database, in Lithuania export of goods and services in 2000 amounted to $44 \%$ of total GDP, while in the EU-27 it was 33\%. However, taking into account the share of import in terms of general GDP, in Lithuania it was $46 \%$, whereas in the EU-27 it was $32 \%$. So, the results reveal that Lithuania consumed more imported goods and services than the EU-27. Therefore, in Lithuania the share of import is larger than of export. Thus, production level in Lithuania is lower than in the EU-27 in general.

Notwithstanding, during the prosperous economic period (2000-2007) CO2 equivalent emissions from the production-based perspective in Lithuania increased faster than in the 


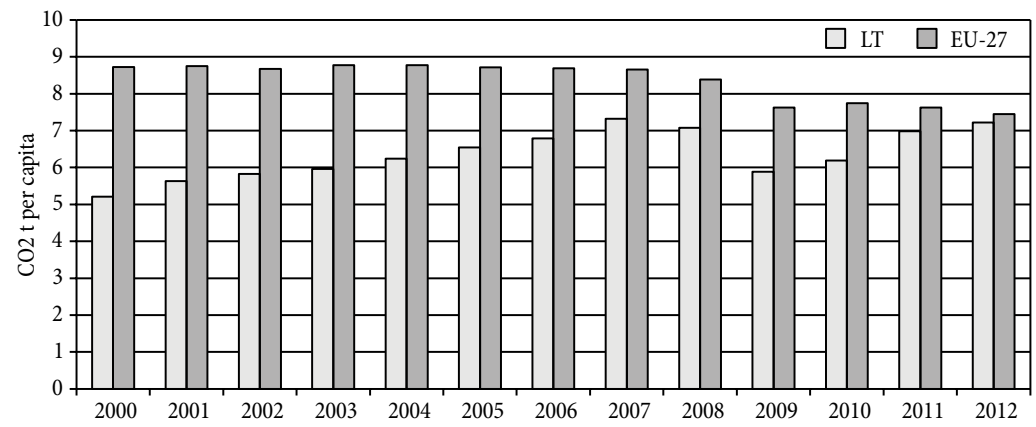

Fig. 2. Annual changes in $\mathrm{CO} 2$ equivalent emissions per capita from the total economic activity in Lithuania, compared with the mean change of the EU-27 member states

EU-27 members. In Lithuania during 2000-2007 greenhouse gas emissions increased by 40\%. Meanwhile in the EU-27 member states GHG emission barely changed (Fig. 2). These alterations revealed fast Lithuanian catch-up process with the EU-27 average. Therefore, Lithuania approached from $60 \%$ to $85 \%$ the EU-27 average between 2000 and 2007 (Fig. 3). However, it needs to be taken into consideration that GDP in Lithuania during prosperous economic period grew by $72 \%$, while in the EU-27 - by $17 \%$. Additionally, taking into account $\mathrm{CO} 2$ equivalent emissions intensity, in Lithuania its decrease was more significant (by 18\%) than in the EU-27 (by 15\%). Therefore, Lithuanian catch-up process with regard to GHG emissions can be evaluated rather positively from sustainable development perspectives.

During economic crisis situation in Lithuania and in the EU-27 regarding GHG pollution changed. In 2008-2009 CO2emission in Lithuania decreased more significantly (by 17\%) than in the EU-27 members (by 9\%) (Fig. 2). Taking into account that GHG emission intensity from production decreased at the same rate both in Lithuania and in all the EU member states - by $5 \%$, in Lithuania the shrinkage of $\mathrm{CO} 2$ emissions pertains mostly to a larger decline in production (it decreased by 15\%) in comparison with the EU-27 average (production decreased by $5 \%$ ). Hence economic crisis, due to reduction of export and foreign investment, affected Lithuanian production more considerably (Criste et al. 2011; Aslund 2011) than the one of EU-27 member states in general.

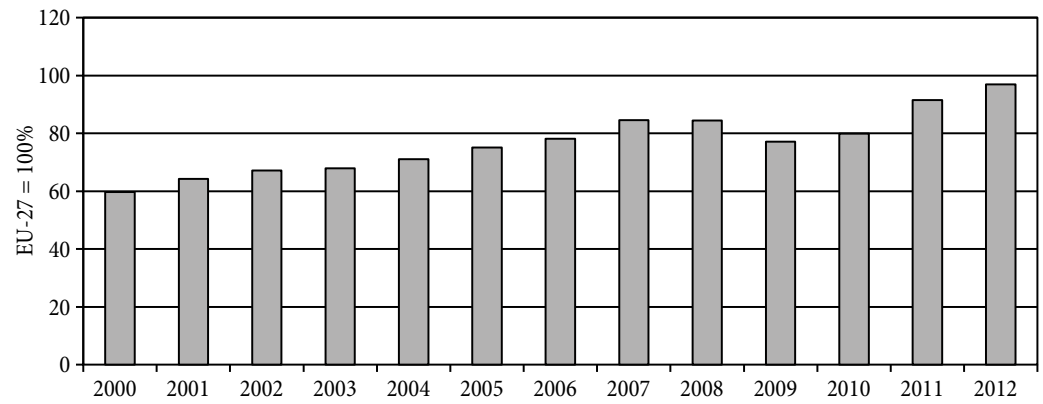

Fig. 3. Lithuanian volume index of $\mathrm{CO} 2$ equivalent emissions per capita from total economic activities, compared with the EU-27 average 
Furthermore, during economic recovery growth in GHG emissions was observed again in Lithuania. Since 2009 to 2012 CO2 equivalent emissions increased by $22 \%$. Meanwhile, in the EU-27 the emissions decreased by 2\% (Fig. 2). Thus, Lithuania in 2012 reached almost $97 \%$ of the EU-27 level (Fig. 3). This fact is negatively emphasized as GHG emission intensity in Lithuania grew by $10 \%$, while in the EU-27 countries it decreased (by 6\%). Therefore, coming further into the period of economic growth, Lithuania should attempt to stabilize GHG emissions so that they would not increase or, even better, would decrease.

Separate economic activities need to be analyzed before undertaking an exercise in future projection from a production perspective. Thus changes in $\mathrm{CO} 2$ equivalent emissions from separate economic activities were different in Lithuania, the EU-27 and among separate the EU-27 countries as well. In Lithuania during analyzed period (2000-2012) the reduction of $\mathrm{CO} 2$ emissions was observed in mining and quarrying, construction, electricity, gas, steam, air conditioning supply and water supply, and wholesale and retail trade. Nevertheless, in the EU-27 member states the reduction of $\mathrm{CO} 2$ emissions was observed for all economic activities with exception of post and telecommunications, financial and insurance activities, other service activities and transportation and storage. Emissions from the latter economic activities in Lithuania increased almost five times in comparison with the EU-27 members (Table 1).

Hence CO2 emissions of mining and quarrying, electricity, gas, steam, air conditioning supply and water supply, construction, and wholesale and retail trade in Lithuania decreased more considerably than in the EU-27 member states. However, CO2 emissions from residual economic activities in Lithuania increased more significantly or decreased at lower rate than in the EU-27 countries. Therefore, it is very important to analyze determinants that influence the latter changes.

Table 1. Changes in $\mathrm{CO} 2$ equivalent emissions from separate economic activities expressed as percentage during 2000-2012 in Lithuania and the EU-27 member states

\begin{tabular}{lcc}
\hline & LT & EU-27 \\
\hline Agriculture, forestry and fishing & 12.3 & -8.9 \\
\hline Mining and quarrying & -52.8 & -35.7 \\
\hline Manufacturing & 21.1 & -23.5 \\
\hline Electricity, gas, steam, air conditioning supply and water supply & -24.6 & -5.6 \\
\hline Construction & -6.8 & -2.9 \\
\hline Wholesale and retail trade & -1.9 & -1.8 \\
\hline Transportation and storage & 54.3 & 11.5 \\
\hline Post and telecommunications & 52.0 & 0.2 \\
\hline Financial and insurance activities & 62.9 & 9.2 \\
\hline Real estate activities & 22.0 & -17.2 \\
\hline Public administration and defence & 12.4 & -14.0 \\
\hline Education & 65.1 & -7.8 \\
\hline Human health and social work activities & 34.1 & -0.6 \\
\hline Other service activities & 20.0 & 0.6 \\
\hline
\end{tabular}


Additionally, differences in $\mathrm{CO} 2$ equivalent emissions from production-based perspective in Lithuania and the EU-27 member states are associated with distinction in economic growth and technological development. These determinants are analyzed in the next sections.

\subsection{Economic impact on $\mathrm{CO} 2$ emission changes from production-based perspective}

GHG emissions from production-based perspective occur mostly due to the growth of production level (Jobert et al. 2010; Girod, Haan 2010; Finel, Tapio 2012). Nevertheless, with production (economic) growth it is very important that negative environmental impact should increase at a slower rate or slow down. These changes are defined as the decoupling process and are revealed by the elasticity coefficient (Vehmas et al. 2003, 2007; Kerkhof et al. 2009; Jobert et al. 2010; Girod, Haan 2010; Finel, Tapio 2012).

Analysis of total economic activities showed a significantly lower than 1 but positive elasticity coefficient was observed only in Lithuania. It reveals that relative decoupling occurred. Thereby during the period of 2000-2012, with economic growth being $1 \%$, CO2 emissions in Lithuania grew by $0.35 \%$. In other words, Lithuanian economy grew three times faster than emissions of CO2. Meanwhile, the elasticity coefficient of all industries in the EU-27 member states was negative. It shows that with economic growth the emissions of GHG decreased, even though this relationship was insignificant (Table 2). Thus Lithuania should make additional efforts in order to pursue reduction of GHG emission.

According to separate economic activities, in Lithuania and the EU-27 countries negative elasticity coefficient was estimated for electricity, gas and water supply and other services, which implies absolute decoupling, i.e. with the growth of gross value added, emissions of $\mathrm{CO} 2$ from these activities decreased, even though this relationship was insignificant (Table 2). From environmental perspectives it is certainly viewed very positively. This positive change in electricity sector was caused by increased share of renewable energy in electricity supply. According to Eurostat database, in Lithuania it grew from $3.5 \%$ to $10.9 \%$ between 2004 and 2012. Meanwhile, in the EU-27 it grew from $15.2 \%$ to $23.1 \%$. Thus the share of renewable resources in the EU-27 countries in 2012 was 2.1 times bigger than in Lithuania. Therefore, Lithuania is rather behind with the share of renewable energy in electricity supply, even though much has been done to achieve the EU level.

Furthermore, in the EU-27 member states a negative and significant elasticity coefficient, which reveals absolute decoupling, was observed for agriculture, forestry and fishing, real estate activities, public administration, defenceand education. Meanwhile, in Lithuania significant, positive and higher than 1 elasticity coefficient was estimated for public administration, defence and education. In addition, significant and higher than 1 elasticity coefficient was observed for human health and social work activities as well as financial and insurance activities. Thus it reveals that for these activities a negative decoupling process occurred in Lithuania (Table 2). Hence services sectors in Lithuania were not efficient enough and increased more than VA. However, these changes have to be evaluated very cautiously, because there could be related to errors in the air emissions account. Notwithstanding, service sector is characterized by small degree of openness toward external markets (Butnar, Liop 2011). So, in Lithuania it is very important to improve management of services in order to make them more efficient. 
Table 2. Elasticity coefficient by economic activity in the period 2000-2012

\begin{tabular}{lcc}
\hline & LT & EU-27 \\
\hline Total - all economic activities & $0.35^{\star}$ & -0.43 \\
\hline Agriculture, forestry and fishing & 0.12 & $-0.35^{\star}$ \\
\hline Mining and quarrying & $1.8^{\star}$ & $0.96^{\star}$ \\
\hline Manufacturing & 0.38 & -0.28 \\
\hline Electricity, gas, steam, air conditioning supply and water supply & -0.17 & -0.27 \\
\hline Construction & $0.27^{\star}$ & $0.6^{\star}$ \\
\hline Wholesale and retail trade & $0.48^{\star}$ & -0.15 \\
\hline Transportation and storage & $0.46^{\star}$ & $1.36^{\star}$ \\
\hline Post and telecommunications & $0.92^{\star}$ & $0.25^{\star}$ \\
\hline Financial and insurance activities & $1.4^{\star}$ & $0.23^{\star}$ \\
\hline Real estate activities & $0.98^{\star}$ & $-0.75^{\star}$ \\
\hline Public administration and defence & $1.82^{\star}$ & $-1.5^{\star}$ \\
\hline Education & $2.44^{\star}$ & $-1.3^{\star}$ \\
\hline Human health and social work activities & $1.35^{\star}$ & -0.17 \\
\hline Other service activities & -0.13 & -0.46 \\
\hline
\end{tabular}

Note: ${ }^{\star} \mathrm{p}<0.05$.

As for agriculture, forestry and fishing activities, in Lithuania the growth of VA from agriculture also had positive though insignificant effect (Table 2). Thus Lithuania in terms of agriculture should pursue absolute decoupling of $\mathrm{CO} 2$ emissions which occurred in the EU-27 countries generally. Therefore, in Lithuania the European Common Agriculture Policy (CAP) should be strictly implemented by encouraging agricultural intensification, including sustainable use of chemical inputs, increasing field size and higher stocking densities (Erisman et al. 2008). The transition of the CAP towards the decoupling and linkage of single farm payments in compliance with environmental legislation as well as expansion of organic farming area are important drivers for environmental impact reduction regarding agriculture in Lithuania.

Taking analysis further, in Lithuania positive, lower than 1 but significant elasticity coefficient was observed for wholesale and commission trade, real estate, post and telecommunications, construction, and transport and storage economic activities. Insignificant elasticity coefficient was observed for manufacturing. These results show that during the period of 2000-2012 relative decoupling occurred for these economic activities in Lithuania, when VA grew faster than CO2 emission. However, in the EU-27 member states significant relative decoupling was observed only for construction, financial and insurance activities, and post and telecommunications. And elasticity coefficient for wholesale and commission trade, human health and social work activities and manufacturing in the EU27 was negative, but insignificant.

Considering the transport sector in Lithuania, GHG emissions increased at slower rate with the boost of VA. Meanwhile, in the EU-27 CO2 emissions from this sector increased more than VA. Thus negative decoupling occurred, which is viewed very negatively. This was caused by the fact that according to the Eurostat database during 2004-2012 in Lithu- 
ania the share of renewable energy in transport sector increased three times in comparison with the EU-27 average. Moreover, according to composition of inland freight transport, in the EU-27 the share of road freight transport in 2010 was $76 \%$, while in Lithuania it was $59 \%$. Meanwhile, the share of less polluting and more environmentally friendly railway transport in Lithuania was $41 \%$, whereas in the EU-27 it was only $17 \%$.

Furthermore, in the EU-27 a significantly positive elasticity coefficient was observed for mining and quarrying economic activity. It was higher than 1 in Lithuania, (Table 2). In addition, this coefficient in Lithuania reveals recessive decoupling when $\mathrm{CO} 2$ emissions from the latter activity decreased more than VA and from the perspective of sustainable development this is viewed very positively.

Achieving that in Lithuania and all the EU members CO2 emissions would increase more slowly than economic growth is very important. One way to achieve reduction of GHG emissions, according to I. Butnar and M. Liop (2011), is by fostering economic growth in less polluting economic activities, such as services. However, S. Voigt et al. (2014) declared that changes in the structure of production contribute to changes in emissions only from a short-term perspective, as it depends on economic fluctuations. Therefore, when pursuing long-term aims the most important issue is to promote technological improvements. In the following section technological and other instruments intended for implementation of cleaner production and contribution to changes in GHG emissions will be analyzed.

\subsection{Technological contributions to changes in $\mathrm{CO} 2$ equivalent emissions from the production-based perspective}

Economies with more advanced technology exhibit more productive efficiency. Thus economy is always pursuing for a high-efficiency state, which leads to an increase in the number of leading industries regarding technological progress and innovative growth. In this study technological contributions to changes in $\mathrm{CO} 2$ equivalent emissions from the productionbased perspective were examined. Thus Figure 4 shows that in Lithuania the contribution of technology, which is related to the reduction of GHG emissions intensity, is not positive in all occasions. For financial and insurance activities, education, post and telecommunications, and other service activities CO2 emissions in 2012 were larger with real pollution changes in comparison with the assumed scenario (Fig. 4). These results reveal that the emission intensity coefficient in 2012 of the latter activities was more considerable than in 2000. Therefore, service management system in Lithuania needs to be improved so that it would result in higher efficiency according to its environmental impact.

Taking analysis further, in Lithuania the smallest technology contribution was observed for human health activities and agriculture, forestry and fishing (Fig. 4). It shows that GHG emissions from these activities increased at the same rate as value added. Therefore, modernization of Lithuanian agricultural sector is one of the most important matters in seeking the aims of GHG emissions management policy.

The majority of technological contribution in Lithuania was observed for construction, wholesale and retail trade, mining and quarrying and manufacturing sectors. In 2012 (in comparison to 2000) technological improvements and other innovations contributed to CO 2 emission reduction approximately by $40-53 \%$ in the above mentioned sectors. It is 
positively very positive change. T. Baležentis et al. (2013) also revealed that in Lithuania manufacturing activities, particularly pharmaceutical ones, wood, food and furniture production exhibited the best performance according to the efficiency. Indeed, these sectors received substantial foreign investment and thus modernized their production technologies.

In Lithuania in 2012, in comparison with 2000, technologies contributed to reduction of $\mathrm{CO} 2$ emissions from all economic activities by $30 \%$ (Fig. 4). However, it did not offset the GDP growth and in Lithuania there was observed the GHG emission growth during the analysed period. Meanwhile, in the EU-27 member states the contribution of technology at $24 \%$ was negligibly lower (Fig. 5). However, in the EU-27 GHG emissions decreased.

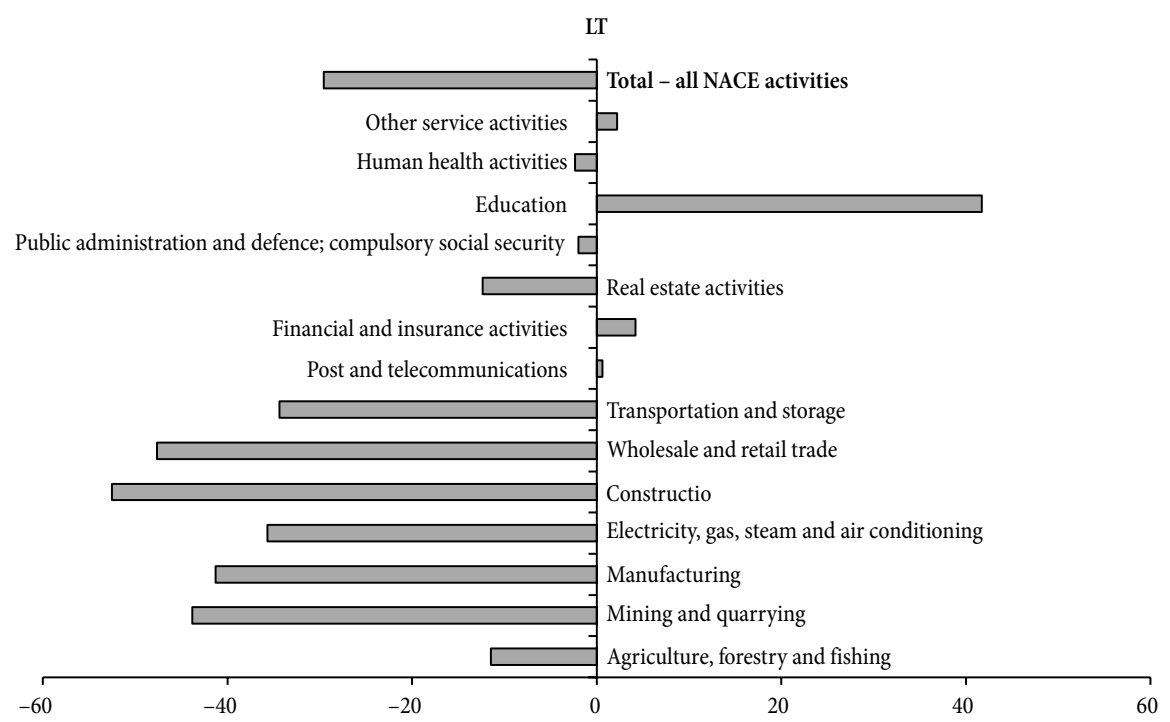

Fig. 4. Technological contribution expressed as percentage during 2000-2012 in Lithuania

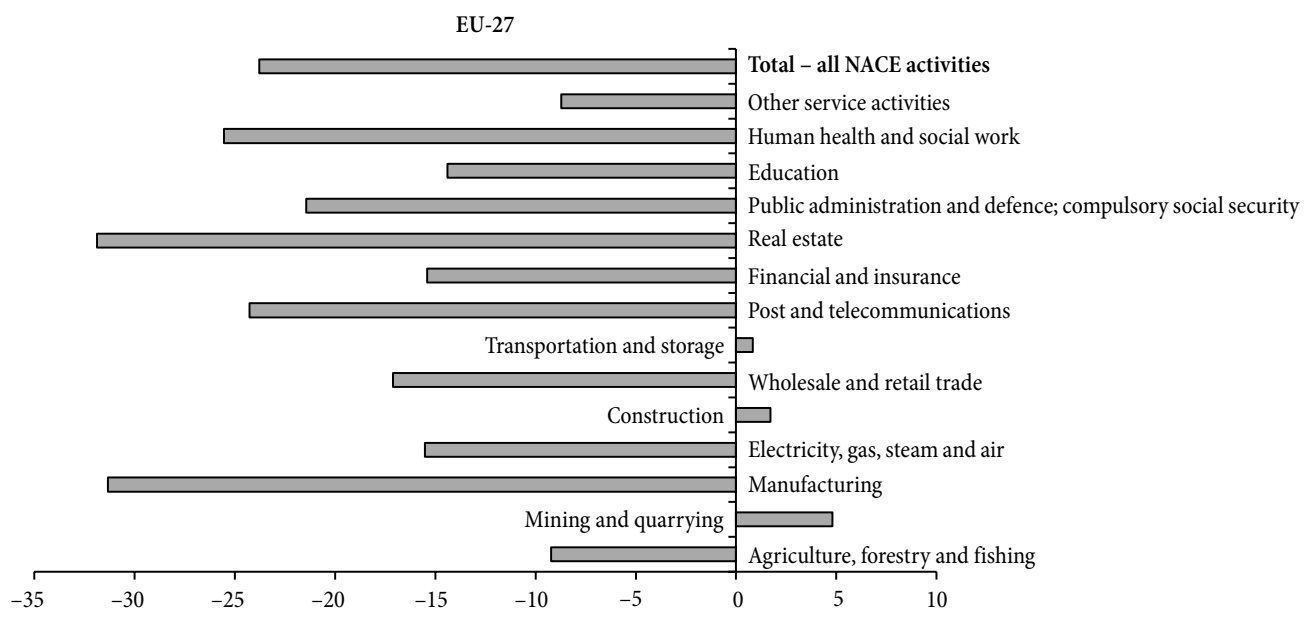

Fig. 5. Average of technological contribution expressed as percentage during 2000-2012 in the EU-27 member states 
In the EU-27 member states one of the largest contributions of technology was observed in manufacturing sector (31\%), however, this percentage in Lithuania was higher. In addition, the EU-27 member states differ from Lithuania in the case of services. The technological contribution to education, financial and insurance, public administration and defence, real estate activities, human health and social work activities as well as post and telecommunication and other service activities was observed as rather significant in the EU-27, although it was negative or very low in Lithuania (Figs 4, 5).

However, the most problematic sectors in the EU-27 member states in general are mining and quarrying, construction, and transport and storage. In terms of mining and quarrying, and construction economic activities, the pollution decreased less than VA. Additionally, taking in to account transport and storage sector, with economic growth $\mathrm{CO} 2$ emission intensity in 2012 was higher than in 2000. Therefore, generally in all the EU-27 member states the main issue is to promote a more efficient transport and storage sector that would reduce $\mathrm{CO} 2$ emission intensity.

\subsection{GHG emissions management policy}

The success of a common climate policy in the long run could contribute to a downward trend regarding the level of the carbonization index in Europe (Padilla, Duro 2013). The main document at the EU level is the EU Energy and Climate Package, which was adopted for transforming Europe gradually into a low carbon economy in 2008 by the European Parliament (Streimikiene 2012). Agreement has been reached to attain legally binding targets by 2020 .

As for requirements of the Climate Change and Energy Package, climate change mitigation goals will be sought in two directions: the EU emissions trading system (ETS) sectors and non-ETS sectors. The EU ETS requirements are applied to combustion plants of more than $20 \mathrm{MW}$ (in boilers and power plants, cement and lime, crude oil processing, ceramics, glass, wood and paper, bricks and tiles and rock wool production plants). Since 2012 the EU ETS includes aviation and chemical production plants. The non-ETS sectors include transport, agricultural, waste management or industrial installations engaged in other types of activities or combustion plants with installed boiler power of less than $20 \mathrm{MW}$ (small district heating installations), public sector buildings, households, agriculture, transport, fishing, construction, services and other sectors.

Lithuanian government approved a national strategy for climate change management policy (2012). In this strategy EU ETS and non-ETS sectors are included as well. A special climate change mitigation goal in EU ETS sectors is to achieve that the GHG emissions in EU ETS sectors in 2020 would not exceed 8.53 million tons of CO2. This should ensure the implementation of the goals regarding the use of renewable energy sources (RES) and increase energy efficiency. Meanwhile, special climate change mitigation targets in nonETS sectors are foreseen since 2013 to 2020 with a 30\% target that GHG emissions from transport, agriculture and industry will be stabilized. Also, in 2020 in comparison with 2013 emissions should slightly decrease.

Thereby, in the agriculture sector it is very important to support the implementation of measures for the cost-effective decrease of methane and nitrogen compounds emis- 
sions from manure management systems. At the EU level the GHG emissions management policy for agriculture is described in the communication "The CAP towards 2020: meeting the food, natural resources and territorial challenges of the future" (COM (2010) 672 final (EC 2010b)). This communication describes major policy options and sets strategic goals such as support for farming communities, which provide European citizens with a valuable variety of good quality foodstuffs produced in a sustainable manner, taking into consideration our aspirations related to requirements for the environment. Also, in this strategy it is highlighted that it is important to further unlock the agricultural sector's potential to mitigate GHG emission via improvements in energy efficiency, biomass and renewable energy production while keeping the structure of the CAP rural development where member states draw up and co-finance multiannual programmes under a common framework.

In Lithuania the main strategic document for agriculture sector is the Lithuanian Rural Development Strategy 2007-2013. In this strategy, while considering GHG emissions, the promotion of organic farming targeted at the production of organic products and a fforestation of degraded land there was included. In the Rural Development Strategy 2014-2020 one of the long-term aims is also to safeguard sustainable resource management and climate policy actions. Considering that the GHG emissions from agriculture in Lithuania in the period of 2000-2011 increased, therefore, pursuing the aims of the climate change management policy (2012) for emissions from agriculture to be stabilized and decreased, Lithuania should make additional efforts to reach these targets.

In addition, energy and industry sectors are very important for implementing eco-innovative measures, increasing energy efficiency and using renewable resources (Jobert et al. 2010; Girod, Haan 2010; Kuramochi et al. 2012; Butnar, Liop 2011; Fernández González et al. 2014; Streimikiene, Baležentis 2013; Streimikiene et al. 2012; Streimikiene 2012). At the EU level the main document describing this policy is Directive 2009/28/EC on the promotion of the use of energy from renewable sources. The requirements of this Directive are to achieve the share of RES in final energy consumption of no less than $23 \%$, and in the transport sector $-10 \%$ by 2020 . These targets in Lithuania have been incorporated into the National Energy Independence Strategy (2012), National Strategy for the Development of Renewable Energy Sources (2010) and the Republic of Lithuania Law on Energy from Renewable Sources (2011).

However, C. Klessman et al. (2011) stated that many the EU members have a very low policy effectiveness and deployment status for almost all renewable energy sources. I. Roos et al. (2012) also revealed that in Lithuania there are insufficient amount of incentives to promote the use of renewable energy since the Lithuanian Government has committed to build a new nuclear power plant. Therefore, it is very important to make additional policy efforts to implement these targets regarding the share of renewable energy in gross final energy (Klessman et al. 2011; Kitzing et al. 2012).

Furthermore, Directive 2006/32/EC on energy end-use efficiency and energy services aims at promoting a cost-effective increase in energy end-use efficiency in the EU-27. This is being realised by setting necessary target indicators, mechanisms and incentive measures, and by enabling the development and promotion of energy services market as well as provision of other measures for increasing energy efficiency to end users. This Directive 
provided the basis for the Energy Efficiency Action Plan in Lithuania (Energy Efficiency Action... 2007). However, A. Baležentis et al. (2011) found that in Lithuania during the period of 1995-2009 the most problematic sectors were transport and services. Moreover, it is also very important to decrease energy intensity in industry and construction sectors (Baležentis et al. 2011).

In "Energy 2020 - A Strategy for competitive, sustainable and secure energy" $(\operatorname{COM}(2010) 639$ final (EC 2010a)) the implementation of ensuring energy saving and eco-design requirements for energy-intensive products is also foreseen. However, as environmental management systems, eco-design and eco-labelling are voluntary environmental policy tools, these practices are still not being considered by industry and other stakeholders as primary options in Lithuania (Staniškis et al. 2008). Therefore, voluntary agreements with more energy intensive enterprises and industries as well as new policies and measures, such as white certificates or energy intensity standards, need to be implemented in Lithuania.

In the transport sector it is important to implement measures which enhance energy efficiency and increase the number of journeys made by bicycle, public road transport and public rail transport. An increase in alternative energy sources and greener fuels should also be included in the energy mix. Therefore, the EU level Regulation (EC) No 443/2009 has been approved. It sets emission performance standards for new passenger cars aiming to attain the Community's goal of achieving an average emission standard of $95 \mathrm{~g} \mathrm{CO} 2 /$ $\mathrm{km}$ for new vehicles. This regulation will come into force in 2020. Additionally, Regulation (EU) No 510/2011 sets emission performance standards for new light commercial vehicles. The standards establish average of $175 \mathrm{~g} \mathrm{CO} 2 / \mathrm{km}$ and of $147 \mathrm{~g} \mathrm{CO} 2 / \mathrm{km}$ emissions in 2014 and 2020 respectively. These standards will be achieved through the enhancement of vehicle technology. Moreover, Commission Regulation (EC) No 692/2008 concerns motor vehicles with respect to emissions from light passenger and commercial vehicles (Euro 5 and Euro 6) and on access to vehicle repair and maintenance information (OJ 2008 L 199:1). Furthermore, Directive 2009/33/EC on the promotion of clean and energy-efficient road transport vehicles lays down requirements for the procurement of vehicles, taking into account the lifetime impact of the vehicle on energy and the environment, including energy consumption and $\mathrm{CO} 2$ emissions and the volume of some other pollutants. Besides, vision of the EU transport sector in 2050 is laid down in the White Paper "Roadmap to a Single European Transport Area - Towards a competitive and resource efficient transport system" (COM(2011) 144 (EC 2011a)). It sets development priorities and paths for this sector. The main goals are to halve the use of "conventionally-fuelled" cars in urban transport by 2030 and phase them out the cities by 2050. Compared to 1990 level, a 60\% GHG emission reduction target is to be achieved in 2050 .

In Lithuania for transport sector a long-term (until 2025) Strategy for the Development of the Lithuanian Transport System has been approved (2005). These measures contribute to the GHG emission reduction goals and are focused on the renewal of transport fleets, the improvement of the road infrastructure (paving of gravel roads, and introduction of walking and cycling routes), the use of greener fuel (by increasing the share of RES in the fuel mix in the transport sector) and the promotion of the use of less polluting vehicles. 
The Strategy aims to achieve that indigenous biological resources would account for $15 \%$ of transport fuel requirements. However, our results revealed that during the period 20002011 GHG emissions increased in transport sector the most. Moreover, A. Baležentis et al. (2011) declared that Lithuania obviously lacks effective policies in transport sector and financial instruments to support the use of hybrid and electric vehicles. Finally, improvement of road infrastructure and public transport modernization are necessary in Lithuania.

\section{Conclusions}

Greenhouse gases emission from production-based perspective amounts to about $83 \%$ of total CO2 equivalent emission in the EU-27 members, while in Lithuania it amounts to 95\%. Lithuania approached the EU-27 members' average of CO2 equivalent emissions due to the fast economic growth during the period of economic prosperity and successful economic recovery. However, according to elasticity coefficient in Lithuania during the period analyzed the economy grew three times faster than emissions of CO2. Meanwhile, in the EU-27 member states with economic growth emissions of GHG decreased, though insignificantly. Thus, considering that generally in the EU-27 countries the absolute decoupling process there was observed, Lithuania should make additional efforts in order to pursue reduction of GHG emissions.

Lithuania in comparison with the EU-27 performed better regarding mining and quarrying, electricity, gas, steam, air conditioning supply, water supply, construction and wholesale and retail trade activities, as $\mathrm{CO} 2$ emissions of these economic activities decreased more than in the EU-27 member states. However, CO2 emissions from residual economic activities in Lithuania increased more or decreased at the lower rate than in the EU-27 countries.

Regarding coefficient of elasticity, absolute decoupling, though insignificant, was observed for electricity, gas, steam, air conditioning supply and water supply, and other service activities in Lithuania. Generally, in the EU-27 from the perspective of sustainable development positive progress (absolute decoupling) was evaluated for agriculture, forestry and fishing, public administration, defence economic activities, real estate activities, and education. Meanwhile, in Lithuania for these activities a relative or negative decoupling occurred. Therefore, in Lithuania the European Common Agriculture Policy should be implemented more widely and service management should be improved as well. In the EU-27 member states CO2 equivalent emissions grew faster than VA for the transport and storage sector, so consequently the main issue for all the EU-27 member states generally is to promote higher efficiency in this sector.

In regard to the study of technological contribution to changes in $\mathrm{CO} 2$ equivalent emissions, the most problematic economic activities in Lithuania are: financial and insurance activities, education, post and telecommunications, other service activities. Thus for these activities Lithuania should put more efforts to reduce emission intensity in order to improve the present situation. In the EU-27 members in general the most problematic sectors are transport and storage, construction, mining and quarrying sectors. 
Thus, the successful implementation of climate policy in the long run could contribute to a downward trend regarding the level of GHG emissions. Therefore, it is very important that Lithuania and the EU successfully fulfill the commitments stated in the documents reviewed. However, particularly in Lithuania, there are insufficient amount of incentives to promote the use of renewable energy. Also, there is a lack of effective policies in environmental management systems. Furthermore, eco-design and eco-labelling tools are still not considered by industry and other stakeholders as primary options. Therefore, in Lithuania it is very important to promote the use of renewable energy, voluntary environmental policy tools in industry as well as increase energy efficiency.

\section{References}

Alves, M. R.; Mountinho, V. 2013. Decomposition analysis and Innovative Accounting Approach for energy-related CO2 (carbon dioxide) emissions intensity over 1996-2009 in Portugal, Energy 57: 775-787. http://dx.doi.org/10.1016/j.energy.2013.05.036

Arazmuradov, A.; Martini, G.; Scotti, D. 2013. Determinants of total productivity in former Soviet Union economies: a stochastic frontier approach, Economy Systems 38(1): 115-135. http://dx.doi.org/10.1016/j.ecosys.2013.07.007

Aslund, A. 2011. Lessons from the East European Financial Crisis, 2008-10. Policy Briefs PB11-9. Peterson Institute for International Economics.

Baležentis, A.; Baležentis, T.; Streimikiene, D. 2011. The energy intensity in Lithuania during 1995-2009: a LMDI approach, Energy Policy 39: 7322-7334. http://dx.doi.org/10.1016/j.enpol.2011.08.055

Baležentis, T.; Misiūnas, A.; Baležentis, A. 2013. Efficiency and production change across the economic sectors in Lithuania (2000-2010) the Dea-Multimoora approach, Technological and Economic Development of Economy 19(Supplement 1): S191-S213. http://dx.doi.org/10.3846/20294913.2013.881431

Brizga, J.; Feng, K.; Hubacek, K. 2014. Drivers of greenhouse gas emissions in the Baltic States: a structural decomposition analysis, Ecological Economics 98: 22-28.

http://dx.doi.org/10.1016/j.ecolecon.2013.12.001

Butnar, I.; Liop, M. 2011. Structural decomposition analysis and input-output subsystems: changes in CO2 emissions of Spanish service sectors (2000-2005), Ecological Economics 70: 2012-2019. http://dx.doi.org/10.1016/j.ecolecon.2011.05.017

Camarero, M.; Picazo-Tadeo, A. J.; Tamarit, C. 2008. Is the environmental performance of industrialized countries converging? A "SURE" approach to testing for convergence, Ecological Economics 56: 653-661. http://dx.doi.org/10.1016/j.ecolecon.2007.10.024

Camarero, M.; Picazo-Tadeo, A. J.; Tamarit, C. 2013. Are determinants of CO2 emissions convergence converging among OECD countries?, Economic Letters 18: 159-162.

http://dx.doi.org/10.1016/j.econlet.2012.10.009

Criste, A.; Lupu, I.; Milea, C.; Ailinca, A. G. 2011. The reflection of the current crisis on the economic growth in the European Union New Member States, Acta Univesitatis Danubius 2: 58-68.

Dai, F.; Liu, J.; Liang, L. 2013. Industry segmentation under environmental pressure an optimal approach, Technological and Economic Development of Economy 19(Supplement 1): S524-S543. http://dx.doi.org/10.3846/20294913.2014.880081

de Leeuw, F. A. A. M. 2002. A set of emission indicators for long-range transboundary air pollution, Environmental Science \& Policy 5: 135-145. http://dx.doi.org/10.1016/S1462-9011(01)00042-9

Directive 2006/32/EC of the European Parliament and of the Council of 5 April 2006 on energy end-use efficiency and energy services and repealing Council Directive 93/76/EEC (OJ 2006 L 114, p. 64), as last amended by Regulation (EC) No 1137/2008 of the European Parliament and of the Council at 22 October 2008 (OJ 2008 L 311, p. 1). 
Directive 2009/28/EC of the European Parliament and of the Council of 23 April 2009 on the promotion of the use of energy from renewable sources and amending and subsequently repealing Directives 2001/77/EC and 2003/30/EC (OJ 2009 L 140, p. 16).

Directive 2009/33/EC of the European Parliament and of the Council of 23 April 2009 on the promotion of clean and energy-efficient road transport vehicles (OJ 2009, L 120, p. 5).

European Commission (EC). 2010a. Communication from the Commission to the European Parliament, the Council, the European Economic and Social Committee and the Committee of the Regions of 10 November 2010 "Energy 2020 - A Strategy for competitive, sustainable and secure energy". $\operatorname{COM}(2010) 639$ final.

European Commission (EC). 2010b. Communication of 18 November 2010 from the European Commission to the European Parliament, the Council, the European Economic and Social Committee and the Committee of the Regions "The CAP towards 2020: meeting the food, natural resources and territorial challenges of the future". $\operatorname{COM}(2010) 672$ final.

European Commission (EC). 2011a. Commission Communication of 28 March 2011 on White Paper "Roadmap to a Single European Transport Area - Towards a competitive and resource efficient transport system". COM(2011) 144 final.

European Commission (EC). 2011b. A Roadmap for Moving to a Competitive Low Carbon Economy in 2050. Communication (COM(2011) 112). European Commission, Brussels.

European Commission (EC). 2012. Europe 2020: A European Strategy for Smart. Sustainable and Inclusive Growth. Communication COM(2010) 2020 Final European Commission, Brussels.

EEA. 2010. The European environment - state and outlook 2010: synthesis. State of environment report No $1.113 \mathrm{p}$.

Energy Efficiency Action Plan approved by Order No 4-270 of the Minister of Economy of the Republic of Lithuania of 2 July 2007. Official Gazette, No 76-3024, 2007; No 2-38, 2009.

Erisman, J. W.; Bleeker, A.; Hensen, A.; Vermuelen, A. 2008. Agricultural air quality in Europe and future perspectives, Atmospheric Environment 42: 3209-3217. http://dx.doi.org/10.1016/j.atmosenv.2007.04.004

Fernández González, P.; Landajo., M.; Presno, M. J. 2014. The driving forces behind changes in GHG emission levels in EU-27. Differences between member states, Environmental Sciences \& Policy 38: 11-16. http://dx.doi.org/10.1016/j.envsci.2013.10.007

Finel, N.; Tapio, P. 2012. Decoupling transport CO2 from GDP. Finland Future Research Centre FFRC ebook 1/12. $42 \mathrm{p}$.

Freire-Gonzalez, J. 2011. Methods to empirically estimate direct and indirect rebound effect of energysaving technological changes in household, Ecological Modelling 223: 32-40. http://dx.doi.org/10.1016/j.ecolmodel.2011.09.001

Girod, B.; Haan, P. 2010. More or better? A model for changes in household greenhouse gas emissions due to higher income, Journal of Industrial Ecology 14(1): 31-49. http://dx.doi.org/10.1111/j.1530-9290.2009.00202.x

Hammond, G. P.; Norman, J. B. 2012. Decomposition analysis of energy-related carbon emissions from UK manufacturing, Energy 41: 220-227. http://dx.doi.org/10.1016/j.energy.2011.06.035

Herrerias, M. J. 2013. The environmental convergence hypothesis: carbon dioxide emissions according to the source of energy, Energy Policy 61: 1140-1150. http://dx.doi.org/10.1016/j.enpol.2013.06.120

IPCC 1996. Revised 1996 guidelines for national greenhouse gas inventories [online]. The Intergovernmental Panel on Climate Change (IPCC), Hayama, Kanagawa [cited 01 February 2014]. Available from Internet: http://www.ipcc-nggip.iges.or.jp/public/gl/invs1.html

Jobert, T.; Karanfil, F.; Tykhonenko, A. 2010. Convergence per capita carbon dioxide emissions in the EU: Legend or reality?, Energy Economics 32(6): 1364-1373.

http://dx.doi.org/10.1016/j.eneco.2010.03.005 
Kerkhof, A. C.; Nonhebel, S.; Moll, H. C. 2009. Relating the environmental impact of consumption to household expenditure: an input-output analysis, Ecological Economics 58: 1161-1170. http://dx.doi.org/10.1016/j.ecolecon.2008.08.004

Kim, K.; Kim, Y. 2012. International comparison of industrial CO2 emission trends and the energy efficiency paradox utilizing production-based decomposition, Energy Economics 34: 1724-1741. http://dx.doi.org/10.1016/j.eneco.2012.02.009

Kitzing, L.; Mitchell, C.; Morthorst, P. E. 2012. Renewable energy policy in Europe: converging or diverging?, Energy Policy 51: 192-201. http://dx.doi.org/10.1016/j.enpol.2012.08.064

Klessmann, C.; Held, A.; Rathmann, M.; Ragwitz, M. 2011. Status and perspectives of renewable energy policy and deployment in the European Union - what is needed to reach the 2020 targets?, Energy Policy 39: 7637-7657. http://dx.doi.org/10.1016/j.enpol.2011.08.038

Kuramochi, T.; Ramirez, A.; Turkenburg, W.; Faaij, A. 2012. Effect of CO2 capture on the emissions of air pollutants from industrial processes, International Journal of Greenhouse Gas Control 10: 310-328. http://dx.doi.org/10.1016/j.ijggc.2012.05.022

Li, X.; Lin, B. 2013. Global convergence in per capita CO2 emissions, Renewable and Sustainable Energy Reviews 24: 357-363. http://dx.doi.org/10.1016/j.rser.2013.03.048

Liao, H.; Cao, H.-S. 2013. How does carbon dioxide emission change with the economic development? Statistical experience from 132 countries, Global Environmental Change 23(5): 1072-1082. http://dx.doi.org/10.1016/j.gloenvcha.2013.06.006

Lithuanian Rural Development Strategy 2007-2013 and its programme approved by the EU Committee on Rural Development on 19 September 2007.

Liu, Q.; Wang, Q. 2013. Pathway to SO2 emissions reduction in China for 1995-2010: based o decomposition analysis, Environmental Science \& Policy 23: 405-415. http://dx.doi.org/10.1016/j.envsci.2013.08.003

Marin, G.; Mazzanti, M.; Montini, A. 2012. Linking NAMEA and Input output for, consumption vs. Production perspective' analysis. Evidence on emission efficient and aggregation biases using the Italian and Spanish environmental accounts, Ecological Economics 74: 71-84. http://dx.doi.org/10.1016/j.ecolecon.2011.11.005

National Energy Independence Strategy of the Republic of Lithuania approved by Resolution No XI-2133 of the Parliament of the Republic of Lithuania of 26 June 2012.

National Strategy for the Development of Renewable Energy Sources approved by Resolution No 789 of the Government of the Republic of Lithuania of 21 June 2010, Official Gazette, No 73-3725, 2010.

Padilla, E.; Duro, J. A. 2013. Explanatory factors of CO2 per capita emission inequality in the European Union, Energy Policy 62: 1320-1328. http://dx.doi.org/10.1016/j.enpol.2013.07.018

Parikh, J.; Panada, M.; Ganesh-Kumar, A.; Singh, V. 2009. CO2 emissions structure of Indian economy, Energy 34: 1024-1031. http://dx.doi.org/10.1016/j.energy.2009.02.014

Peters, G. P. 2008. From production-based to consumption-based national emission inventories, Ecological Economics 65: 13-23. http://dx.doi.org/10.1016/j.ecolecon.2007.10.014

Regulation (EC) No 443/2009 of the European Parliament and of the Council of 23 April 2009 setting emission performance standards for new passenger cars as part of the Community's integrated approach to reduce $\mathrm{CO}_{2}$ emissions from light-duty vehicles (OJ 2009 L 140, p. 1).

Regulation (EC) No 692/2008 of 18 July 2008 implementing and amending Regulation (EC) No 715/2007 of the European Parliament and of the Council on type-approval of motor vehicles with respect to emissions from light passenger and commercial vehicles (Euro 5 and Euro 6) and on access to vehicle repair and maintenance information (OJ 2008 L 199, p. 1), as last amended by Commission Regulation (EU) No 459/2012 of 29 May 2012 (OJ 2012 L 142, p. 16) (hereinafter: 'Regulation No 692/2008').

Regulation (EU) No 510/2011 of the European Parliament and of the Council of 11 May 2011 setting emission performance standards for new light commercial vehicles as part of the Union's integrated approach to reduce CO2 emissions from light-duty vehicles (OJ 2011 L 145, p. 1). 
Regulation (EU) No. 691/2011 of the European Parliament and of the Council of 6 July 2011 on European Environmental Economic Accounts (OJ 2011 L 192/1, p. 16).

Republic of Lithuania Law on Energy from Renewable Sources 2011 May 12. Official Gazette No XI1375, 2011.

Roos, I.; Soosaar, S.; Volkova, A.; Streimikiene, D. 2012. Greenhouse gas emission reduction perspective in the Baltic States in frames of EU energy and climate policy, Renewable and Sustainable Energy Reviews 16: 2133-2146. http://dx.doi.org/10.1016/j.rser.2012.01.013

Parliament of the Republic of Lithuania. 2012. Resolution approving the national strategy for climate change management policy 6 November 2012 No XI-2375.

Staniškis, K. J.; Varžinskas, V.; Arbačiauskas, V. 2008. Sustainable consumption and production in Lithuania. Environmental research, Engineering and Management 3(45): 23-32.

Strategy for the Development of the Lithuanian Transport System approved by Resolution No 692 of the Government of the Republic of Lithuania of 23 June 2005. Official Gazette, No 79-2860, 2005.

Streimikiene, D. 2012. The impact of international GHG trading regimes on penetration of new energy technologies and feasibility to implement EU Energy Climate Package targets, Renewable and Sustainable Energy Reviews 16: 2172-2177. http://dx.doi.org/10.1016/j.rser.2012.01.042

Streimikiene, D.; Baležentis, T.; Kriščiukiene, I. 2012. Promoting interaction between local climate change mitigation, sustainable energy development and rural development policies in Lithuania, Energy Policy 50: 699-710. http://dx.doi.org/10.1016/j.enpol.2012.08.015

Streimikiene, D.; Baležentis, T. 2013. Multi-objective ranking of climate change mitigation policies and measures in Lithuania, Renewable and Sustainable Energy Reviews: 18: 144-153. http://dx.doi.org/10.1016/j.rser.2012.09.040

The Law on Energy from Renewable Sources. 2011. Official Gazette, No 62-2936.

The Lithuanian strategy for sustainable development. 2009. Approved by Resolution No.1247 on 16 September, 2009 of the Government of the Republic of Lithuania. 96 p.

Turner, K.; Hanley, N. 2011. Energy efficiency, rebound effects and environmental Kuznets Curve, Energy Economics 33: 709-720. http://dx.doi.org/10.1016/j.eneco.2010.12.002

Vehmas, J.; Luukkanen, J.; Kaivo-oja, J. 2007. Linking analyses and environmental Kuznets curves for aggregated material flows in the EU, Journal of Cleaner Production 15: 1662-1673. http://dx.doi.org/10.1016/j.jclepro.2006.08.010

Vehmas, J.; Malaska, P.; Luukkanen, J.; Kaivo-oja, J.; Hietanen, O.; Vinnari, M.; Iivonen, J. 2003. Europe in global battle of sustainability: rebound strikes back? advanced sustainability analysis. Series Discussion and Working Papers. Publications of the Turku School of Economics and Business Administration, vol. 7.

Voigt, S.; Cian, E. D.; Schymura, M.; Verdolini, E. 2014. Energy intensity developments in 40 major economies: Structural change or technology improvement?, Energy Economics 41: 47-62. http://dx.doi.org/10.1016/j.eneco.2013.10.015

Wang, Y.; Zhao, H.; Li, L.; Liu, Z.; Liang, S. 2013. Carbon dioxide drivers for a typical metropolis using input-output structural decomposition analysis, Energy Policy 58: 312-318. http://dx.doi.org/10.1016/j.enpol.2013.03.022

Wood, R. 2009. Structural decomposition analysis of Australia's greenhouse gas emissions, Energy Policy 37: 4943-4948. http://dx.doi.org/10.1016/j.enpol.2009.06.060

Zavadskas, E. K.; Turskis, Z. 2011. Multiple criteria decision making (MCDM) methods in economics: an overview, Technological and Economic Development of Economy 17(2): 397-427. http://dx.doi.org/10.3846/20294913.2011.593291

Zhang, X.-P.; Tan, Y.-K.; Tan Q.-L.; Yuan, J.-H. 2012. Decomposition of aggregate CO2 emissions within a joint production framework, Energy Economics 34: 1088-1097.

http://dx.doi.org/10.1016/j.eneco.2011.09.006 


\section{APPENDIX A}

Table A1. Aggregates of statistical classification of economic activities (NACE rev. 1.1) applied to calculate $\mathrm{CO} 2$ emission and value added in Lithuania and EU-27 member states

\begin{tabular}{cl}
\hline NACE code & \multicolumn{1}{c}{ Economic activity } \\
\hline Total & Total - All NACE activities \\
\hline A & Agriculture, forestry and fishing \\
\hline C & Mining and quarrying \\
\hline D & Manufacturing \\
\hline E & Electricity, gas, steam and air conditioning supply and water supply \\
\hline F & Construction \\
\hline G & Wholesale and retail trade; repair of motor vehicles and motorcycles \\
\hline I & Transportation and storage \\
\hline I64 & Post and telecommunications \\
\hline J & Financial and insurance activities \\
\hline K & Real estate activities \\
\hline L & Public administration and defence; compulsory social security \\
\hline M & Education \\
\hline N & Human health and social work activities \\
\hline O & Other service activities \\
\hline
\end{tabular}

Genovaitė LIOBIKIENĖ, Dr is a junior research scientist at the Department of Drug Technology and Social Pharmacy, Lithuanian University of Health Sciences, Lithuania. Her scientific covers areas of sustainable consumption and production, environmental friendly behaviour and convergence process.

Justina MANDRAVICKAITÉ is a junior research scientist at the Baltic Institute of Advanced Technology, Lithuania. Research interests: integration into the EU, environmental awareness, sustainable development.

Danguolè KREPŠTULIENĖ is chief specialist of the Department of Statistics of Agriculture and Environment at the Statistics Lithuania and is responsible for the data of air emission accounts.

Jurga BERNATONIENE is a Professor at the Department of Drug Technology and Social Pharmacy, Lithuanian University of Health Sciences, Lithuania. Research interests: sustainable development, ecolabelling.

Arūnas SAVICKAS is a Professor at the Department of Drug Technology and Social Pharmacy, Lithuanian University of Health Sciences, Lithuania. Research interests: sustainable development, eco-labelling. 